\title{
Leaf Morphological and Stomatal Variations in Paper Birch Populations along Environmental Gradients in Canada
}

\author{
Anjala Pyakurel, Jian R. Wang \\ Faculty of Natural Resources Management, Lakehead University, Thunder Bay, Canada \\ Email: apyakure@lakeheadu.ca
}

Received 13 March 2014; revised 11 April 2014; accepted 21 April 2014

Copyright (c) 2014 by authors and Scientific Research Publishing Inc.

This work is licensed under the Creative Commons Attribution International License (CC BY). http://creativecommons.org/licenses/by/4.0/

\begin{abstract}
Variations in leaf morphology and stomatal characteristics have been extensively studied at both inter- and intraspecific levels although not explicitly in the context of paper birch (Betula papyrifera Marsh) populations. The birch populations might have developed the leaf variations that allowed them to adapt to a wide climatic gradient. Therefore, in this study we examined variations in the leaf morphological and stomatal characteristics of sixteen paper birch populations collected across Canada and grown in a common garden. We also examined the relationship between these leaf characteristics and the climate of the population's origin. Significant genotypic differences were found in the leaf characteristics measured among the birch populations. Thus, we expected that the observed leaf variations may be partly explained as natural diversity in the birch due to differences in environment of origin. We noticed that along mean annual precipitation and aridity gradients, hair density on leaf adaxial surface had decreased whereas stomatal density increased significantly. Our results showed that the populations with larger leaf area and specific leaf area had higher hair density but low stomatal density. These leaf characteristics provided a structural basis in reducing water loss through leaves and increasing water use efficiency. A trade-off between stomatal area and density resulted in this study might be a strategy of the birch to balance stomatal conductance in decreased precipitation.
\end{abstract}

\section{Keywords}

Leaf Area, Specific Leaf Area, Leaf Adaxial Hair Density, Aspect Ratio, Stomatal Area, Stomatal Density

\section{Introduction}

Plants typically express phenotypic differences in response to environmental changes [1]-[3]. Under different 
environmental conditions, plants allocate biomass in several organs in order to capture optimum light, water, nutrient and carbon dioxide, and as a strategy to maximize growth rate [4]. Phenotypic plasticity also occurred to produce a range of leaf characteristics as a response to environmental effects [5]. These differences in plants particularly at leaf levels are expressed as morphological and anatomical variation.

Leaf morphological and anatomical variation in plants growing in contrasting habitat (i.e. climatic gradient) has long been studied [1] [3]. Leaf morphological studies show that narrow and thick leaves provide structural reinforcement to withstand wilting in hot, sunny and dry environments [6]-[8]. Additionally, it is suggested that small leaves track air temperature closely, whereas large leaves suffer from overheating when water is limited [2]. A study on the adaptive significances of leaf hairs showed an increase in leaf reflectance, boundary layer thickness and prevention in stomatal obstruction by water or particulate matters [9] [10]. Consequently, increased leaf hairs in hot and arid habitats have significant influence in reducing solar radiation, leaf temperature and transpirational losses [9]-[11]. Hence, the most commonly observed leaf morphological changes under water deficiency are reduced leaf area [12] and specific leaf area [12] [13] and increased leaf hairiness [10].

Alternatively, even in abundant water availability the cost for replenishing transpired water is high because of investment in the root and vascular network to transport water [14] [15]. Thus, the most noticed leaf anatomical adaptation to high water transportation cost is stomatal evolution [16]-[20]. Stomata in plants regulate gas exchange under environmental constraints. Leaf stomata optimize between photosynthetic gain and transpirational loss to adjust in precipitation and temperature fluctuations [21]. It is suggested that smaller stomatal area and guard cells increase carbon dioxide diffusion per unit area of stomata and reduce water loss compared to larger stomatal area and guard cells [6]. As an adaptation mechanism to water stress, others show that stomatal density increased in Pseudoroegneriaspicata [22] whereas stomatal area decreased in Pistaciaatlantica [23].

Most of the studies on leaf morphological and stomatal variation in response to environmental variables have either included comparative studies among multiple species [7] [16] [24] or species inhabiting different locations along environmental gradient [6] [7] [25]-[27]. Results of these studies showed marked genetic variation, adaptive significance and phenotypic plasticity in leaf morphology and stomata or both. However, leaf morphological and stomatal variations for multiple species inhabiting different environment do not necessarily explain the variation at intraspecific level. Therefore, it is important to determine whether leaf morphology and stomata differ in wide-ranging pioneer species like paper birch (Betula papyrifera Marsh.) grown in a uniform environment. To our knowledge, no studies have focused on leaf morphological and stomatal variations of the birch populations grown in a uniform environment.

Paper birch adapts to a wide range of climatic and soil moisture regimes in North America, and the species is increasingly significant in commercial forestry [28]. The birch populations may have developed leaf morphological and stomatal variations that have allowed them to adapt to a wide climatic gradient. In this study, we addressed whether leaf morphology and stomata differ among paper birch populations that originate from different environments but grown in the same environment, and whether differences in leaf morphology and stomata are related to the environmental variables of a population's origin. We hypothesized that: (1) leaf morphological and stomatal characteristics vary among the birch populations grown in the uniform environment; (2) leaf characteristics are related to the environmental variables of the populations' origin; (3) the population that originate from warmer regions with less precipitation has smaller leaf area or high leaf hair density; (4) the population that originate from a region with higher precipitation and aridity index has lower stomata density or higher stomatal area; and (5) significant positive relationships exist among stomatal density, stomatal area and leaf hair density.

\section{Materials and Methods}

\subsection{Sample and Leaf Morphological and Stomatal Data Collection}

Seeds of sixteen paper birch populations were collected from Ontario, British Columbia, New Brunswick, Newfoundland, Nova Scotia, Prince Edward Island and Quebec. The populations' origins ranged from 10 - 840 metres elevation, 1639 - $279 \mathrm{~mm}$ mean annual precipitation and $1.36^{\circ} \mathrm{C}-8.88^{\circ} \mathrm{C}$ mean annual temperature across Canada (Table 1). The birch seedlings were grown for 12 weeks in Lakehead University's greenhouse. In August 2008, thirty uniform seedlings in height and root-collar diameter from each population were selected and transplanted in the common garden in Thunder Bay, Ontario (located at 183.3 meters above sea-level, and $48^{\circ} 22^{\prime} \mathrm{N}$ and $\left.89^{\circ} 19^{\prime} \mathrm{W}\right)$. The layout of the populations were following completely randomize design in the garden. 
Table 1. Latitude (Lat.), longitude (Long.), elevation (Elev.) in meters, mean annual precipitation (MAP) in millimeter, mean annual temperature (MAT) in degrees Celsius, mean annual aridity index (MAI), precipitation during growing season (GSP) in millimeter, temperature during growing season (GST) in degrees Celsius, aridity index during growing season (GSA) of sixteen paper birch populations collected (seeds) from across Canada and grown at the common garden in Thunder Bay-Ontario.

\begin{tabular}{|c|c|c|c|c|c|c|c|c|c|}
\hline \multirow{2}{*}{ Populations } & \multicolumn{9}{|c|}{ Environmental Variables } \\
\hline & LAT & LONG & ELE & MAP & MAT & MAI & GSP & GST & GSA \\
\hline Newfoundland & 47.37 & 57.57 & 140 & 1201.90 & 3.83 & 86.91 & 100.08 & 12.00 & 13.50 \\
\hline Milvale & 46.40 & 63.40 & 70 & 1140.70 & 5.23 & 74.90 & 91.00 & 15.08 & 10.77 \\
\hline Cap Des Rosiers & 48.11 & 65.41 & 200 & 1147.20 & 3.33 & 86.06 & 90.78 & 13.33 & 11.55 \\
\hline Allardville & 47.60 & 65.42 & 100 & 969.90 & 3.91 & 69.73 & 90.90 & 15.80 & 10.46 \\
\hline Wayerton & 47.22 & 65.93 & 300 & 1032.60 & 3.99 & 73.81 & 90.90 & 15.80 & 10.46 \\
\hline Indiana Brook & 46.21 & 66.33 & 10 & 1639.50 & 6.16 & 101.45 & 93.85 & 14.13 & 11.54 \\
\hline New Brunswick & 45.54 & 66.38 & 20 & 1124.00 & 5.62 & 71.96 & 90.35 & 16.25 & 10.21 \\
\hline Bell Falls & 46.50 & 75.10 & 330 & 1014.70 & 3.28 & 76.41 & 93.38 & 16.83 & 10.33 \\
\hline Alice & 45.75 & 77.13 & 300 & 829.65 & 4.07 & 58.97 & 83.73 & 16.45 & 9.39 \\
\hline Pettawa & 45.58 & 77.25 & 183 & 853.00 & 4.28 & 59.73 & 76.85 & 16.18 & 8.71 \\
\hline Timmins & 48.27 & 80.80 & 310 & 871.00 & 1.36 & 76.67 & 83.03 & 14.35 & 10.12 \\
\hline Porcupine & 49.15 & 117.00 & 840 & 551.00 & 8.05 & 30.53 & 44.08 & 14.85 & 5.26 \\
\hline Adam Lake & 51.43 & 119.83 & 400 & 1076.50 & 5.01 & 71.72 & 52.33 & 13.38 & 6.64 \\
\hline Skimikin & 50.43 & 120.25 & 547 & 279.00 & 8.88 & 14.78 & 29.55 & 18.50 & 3.08 \\
\hline Tabor Lake & 53.55 & 122.22 & 800 & 600.00 & 5.01 & 39.97 & 52.33 & 13.38 & 6.64 \\
\hline Skeena River & 54.30 & 128.34 & 70 & 1160.00 & 6.32 & 71.08 & 55.00 & 14.18 & 6.75 \\
\hline
\end{tabular}

We randomly harvested leaves from middle of the crown of the birch populations in the common garden in August 2010. Eight healthy, well-developed leaves from each population were collected on randomly chosen individuals for leaf morphological and stomatal analysis following the methods of Warren et al. [2] and Hovenden and Schoor [29] respectively. Leaf morphological characteristics such as leaf area and aspect ratio (horizontal width/vertical length of leaf) were measured using WinFolia software (Regent Instrument Inc. Quebec, Canada). Hair densities on abaxial and adaxial leaf surfaces were counted on three parts $\left(0.20 \mathrm{~cm}^{2}\right)$ of each leaf surface using Academic stere zoom microscope at $30 \times$ magnification and average values were used for further analysis [2] [30] [31]. Subsequently, the leaves were dried at $70^{\circ} \mathrm{C}$ for $42 \mathrm{~h}$ to calculate specific leaf area.

Stomata were absent on the adaxial leaf surface; therefore stomatal replicas were assessed and analyzed for abaxial surface only. We obtained stomatal replicas from middle section of leaves by using clear nail varnish [26]. Leaf veins were avoided as far as possible while collecting stomatal impressions. We used electronic microscope and motic images plus 2.0 ${ }^{\circledR}$ software (Motic Instruments Inc., Richmond, Canada) to obtain photos of stomata. We measured stomatal density (stomata/ $1 \mathrm{~mm}^{2}$ i.e., $10^{6} \mu^{2}$ ), length, width, pore area and guard cell width per leaf for further analysis [16] [32]. The equations used for calculating stomatal characteristics are listed in Table 2 [16] [33]-[35].

\subsection{Climate Variables}

Mean annual and growing season temperature and precipitation data for population's origin were normalized climate data from 1971 to 2001 (Weather-Environment Canada). We calculated the mean annual and growing season annual aridity index using De Martonne's [36] [37] and Sijors's [38] equations respectively (Table 2). 
Table 2. Equations used for leaf morphological and anatomical characteristic; and climate variables of paper birch populations here, SLA: specific leaf area $\left(\mathrm{cm}^{-2} \cdot \mathrm{gm}^{-1}\right)$, LDM: leaf dry mass (gm), LS: leaf area $\left(\mathrm{cm}^{2}\right)$, SA: stomatal area $\left(\mu \mathrm{m}^{2}\right)$, SL: stomatal length $(\mu \mathrm{m}), \mathrm{SW}$ : stomatal width $(\mu \mathrm{m})$, SD: stomatal density, ED: epidermal cell density, PA: stomatal pore surface area $\left(\mu \mathrm{m}^{2}\right)$, PL: pore length $(\mu \mathrm{m}), \mathrm{PW}$ : pore width $(\mu \mathrm{m})$, SI: stomatal intensity, SHC: stomatal shape coefficient, MAI: mean annual aridity index, MAP-mean annual precipitation (millimeters), MAT: mean annual temperature $\left({ }^{\circ} \mathrm{C}\right)$, GSA: mean aridity index during growing season, GSP: mean precipitation during growing season (millimeters), GST: mean temperature during growing season $\left({ }^{\circ} \mathrm{C}\right.$ ) and $\mathrm{Nv}$ : length of growing season (days).

\begin{tabular}{rlrl}
\hline \multicolumn{1}{c}{ Leaf Characteristics } & & Climatic Variables \\
$\mathrm{SLA}$ & $=\frac{\mathrm{LS}}{\mathrm{LDM}}$ & $\mathrm{PA}=\frac{\pi}{4} \times \frac{\mathrm{PL}}{\mathrm{PW}}$ & $\mathrm{MAI}=\frac{\mathrm{MAP}}{\mathrm{MAT}+10}$ \\
$\mathrm{SA}$ & $=\frac{\pi}{4} \times \frac{\mathrm{SL}}{\mathrm{SW}}$ & $\mathrm{SI} \%=\frac{\mathrm{SD}}{\mathrm{SD}+\mathrm{ED}} \times 100$ & $\mathrm{GSA}=\frac{365}{\mathrm{Nv}} \times \frac{\mathrm{GSP}}{10+\mathrm{GST}}$ \\
$\mathrm{SD}$ & $=\frac{\text { No. of stomata }}{\mathrm{LS}}$ & $\mathrm{SHC}=\frac{\mathrm{SW}}{\mathrm{SL}} \times 100$ & \\
$\mathrm{ED}$ & $=\frac{\text { No. of epidermal cells }}{\mathrm{LS}}$ & &
\end{tabular}

\subsection{Data Analyses}

We analyzed the variations in both leaf morphological and stomata characteristics using nonparametric test because of the relatively small sample size for each population [2]. Variations in leaf morphological and stomatal characteristics were analyzed using the Kruskal-Wallis test. We used Mann-Whitney U test to analyze the morphological and stomatal difference between populations. Correlation between measured leaf characteristics and climate of paper birch population's origin were analyzed using Spearman's correlation. We analyzed the relationship between stomatal and morphological characteristics using Spearman's correlation. All statistical analysis was conducted using SPSS-18 (SPSS, Chicago, IL, USA) and R-2.12.1 (R-Development Core team 2011).

\section{Results}

\subsection{Variations in Leaf Morphological and Stomatal Characteristics}

Leaf area, specific leaf area, aspect ratio and leaf hair density showed significant variation among the paper birch populations $(\mathrm{P} \leq 0.05)$ (Table 3). Populations from Porcupine Lake, Wayerton, Pettawa and Adam Lake had significantly larger leaf area in comparison to Newfoundland, which had the smallest leaf area (Table 3). Populations from Wayerton and Milvale had significantly smaller specific leaf area compared to populations from Adam Lake, Porcupine Lake and Skeena River (Table 4). Skimikin had lower leaf abaxial and adaxial hair densities that significantly differed from Adam Lake, Porcupine Lake and Skeena ( $\mathrm{N}=16, \mathrm{P} \leq 0.01)$ (Table 3).

Apart from stomatal index and shape coefficient, analyses of stomatal length, width, and size, pore length, pore width, pore area, stomatal density and guard cell width showed significant differences $(\mathrm{N}=16, \mathrm{P} \leq 0.01)$ among paper birch populations (Table 3, Figure 1). Populations from Newfoundland and Skimikin differed from the majority of populations in stomatal area, pore area and stomatal density. The population from Skimikin had significantly smaller mean stomatal area and higher stomatal density $(\mathrm{N}=16, \mathrm{P} \leq 0.05)$ than those from Adam Lake and Porcupine (Table 3, Figure 1). The population from Adam Lake had the lowest stomatal density, but the largest stomatal area, pore area and guard cell width (Table 3, Figure 1).

\subsection{Correlation between Leaf Characteristics and Climate of Population's Origin}

We found significant correlation between measured leaf characteristics and environmental variables of the paper birch population's origin (Table 4). Leaf area and aspect ratio were positively related to longitude $(\mathrm{r}=0.29$ and 0.33 respectively, $\mathrm{P} \leq 0.001)$, elevation ( $\mathrm{r}=0.26$ and 0.51 respectively, $\mathrm{P} \leq 0.001)$ and growing season temperature ( $r=0.33$ and 0.26 respectively, $\mathrm{P} \leq 0.001$ ); however, they were negatively related to annual and growing season precipitation $(r=-0.33$ and -0.42 respectively, $P \leq 0.001)$ and aridity index $(r=-0.36$ and -0.44 respectively, $\mathrm{P} \leq 0.001$; Table 5). Specific leaf area increased from north to south (latitude) $(\mathrm{r}=0.43, \mathrm{P} \leq 0.001)$ and east to west (longitude) ( $r=0.33, \mathrm{P} \leq 0.001$ ), however, it decreased with increasing growing season temperature $(\mathrm{r}=-0.29, \mathrm{P} \leq 0.001)$, precipitation $(\mathrm{r}=-0.31, \mathrm{P} \leq 0.001)$ and aridity index $(\mathrm{r}=-0.26, \mathrm{P} \leq 0.001$; Table 4). 
Table 3. Results of the Kruskal-Wallis nonparametric tests of leaf morphological and stomatal characteristics (chrs) of 16 paper birch populations collected (seeds) from across Canada and grown at the common garden in Thunder Bay-Ontario.

\begin{tabular}{|c|c|c|c|c|c|c|c|c|c|}
\hline Population & LS & SLA & $\mathrm{AR}$ & $\mathrm{ABH}$ & $\mathrm{ADH}$ & SA & PA & GCW & $\mathrm{SD}$ \\
\hline \multirow{2}{*}{ Newfoundland } & 17.95 & 115.07 & 0.61 & 2.73 & 3.27 & 461.64 & 133.88 & 5.49 & 231.67 \\
\hline & \pm 5.76 & \pm 14.25 & \pm 0.06 & \pm 1.37 & \pm 2.64 & \pm 100.09 & \pm 31.34 & \pm 0.75 & \pm 51.32 \\
\hline \multirow{2}{*}{ Milvale } & 26.18 & 103.06 & 0.65 & 0.73 & 1.47 & 667.49 & 220.14 & 6.48 & 220.00 \\
\hline & \pm 2.39 & \pm 0.01 & \pm 0.03 & \pm 0.72 & \pm 1.46 & \pm 52.38 & \pm 37.99 & \pm 0.33 & \pm 51.96 \\
\hline \multirow{2}{*}{ Cap De Rosiers } & 18.74 & 112.92 & 0.63 & 2.71 & 5.33 & 520.00 & 168.31 & 5.41 & 186.67 \\
\hline & \pm 8.11 & \pm 0.01 & \pm 0.12 & \pm 2.49 & \pm 2.04 & \pm 49.87 & \pm 33.22 & \pm 0.67 & \pm 55.08 \\
\hline \multirow{2}{*}{ Allardville } & 23.07 & 118.06 & 0.68 & 4.60 & 11.8 & 710.90 & 216.32 & 6.84 & 134.00 \\
\hline & \pm 7.05 & \pm 11.16 & \pm 0.05 & \pm 5.22 & \pm 7.10 & \pm 308.45 & \pm 70.66 & \pm 2.74 & \pm 28.81 \\
\hline \multirow{2}{*}{ Wayerton } & 40.83 & 101.30 & 0.75 & 0.01 & 0.01 & 827.53 & 250.40 & 6.99 & 140.00 \\
\hline & \pm 5.31 & \pm 0.82 & \pm 0.09 & \pm 6.17 & \pm 10.02 & \pm 127.06 & \pm 63.32 & \pm 1.02 & \pm 23.98 \\
\hline \multirow{2}{*}{ Indiana Brook } & 22.55 & 116.24 & 0.59 & 3.24 & 6.31 & 871.24 & 260.44 & 7.20 & 190.00 \\
\hline & \pm 4.42 & \pm 0.001 & \pm 0.04 & \pm 1.52 & \pm 2.55 & \pm 94.66 & \pm 58.52 & \pm 0.82 & \pm 17.32 \\
\hline \multirow{2}{*}{ New Brunswick } & 26.86 & 111.68 & 0.60 & 2.04 & 1.13 & 898.25 & 294.16 & 7.61 & 141.25 \\
\hline & \pm 7.49 & \pm 6.25 & \pm 0.07 & \pm 1.97 & \pm 4.18 & \pm 165.55 & \pm 87.57 & \pm 1.25 & \pm 33.57 \\
\hline \multirow{2}{*}{ Bells Fall } & 32.45 & 100.15 & 0.67 & 1.27 & 6.27 & 625.41 & 193.56 & 6.19 & 176.67 \\
\hline & \pm 12.44 & \pm 0.001 & \pm 0.04 & \pm 2.17 & \pm 5.46 & \pm 140.23 & \pm 52.56 & \pm 0.17 & \pm 30.55 \\
\hline \multirow{2}{*}{ Alice } & 24.83 & 110.28 & 0.70 & 1.23 & 3.18 & 864.15 & 238.29 & 7.93 & 176.67 \\
\hline & \pm 12.43 & \pm 1.13 & \pm 0.07 & \pm 5.24 & \pm 11.13 & \pm 204.80 & \pm 20.34 & \pm 2.36 & \pm 28.87 \\
\hline \multirow{2}{*}{ Pettawa } & 37.27 & 117.94 & 0.68 & 4.20 & 2.87 & 697.61 & 209.95 & 7.15 & 173.33 \\
\hline & \pm 14.04 & \pm 0.001 & \pm 0.08 & \pm 1.04 & \pm 2.01 & \pm 238.71 & \pm 76.05 & \pm 1.34 & \pm 77.67 \\
\hline \multirow{2}{*}{ Timmins } & 23.65 & 120.50 & 0.65 & 6.17 & 10.47 & 590.86 & 210.39 & 5.86 & 173.33 \\
\hline & \pm 6.82 & \pm 6.12 & \pm 0.08 & \pm 2.41 & \pm 5.51 & \pm 142.11 & \pm 46.13 & \pm 1.36 & \pm 58.31 \\
\hline \multirow{2}{*}{ Porcupine Lake } & 42.89 & 123.05 & 0.78 & 8.62 & 13.98 & 1075.39 & 320.50 & 8.58 & 132.00 \\
\hline & \pm 14.05 & \pm 12.92 & \pm 0.08 & \pm 2.31 & \pm 9.16 & \pm 158.75 & \pm 93.00 & \pm 0.84 & \pm 36.33 \\
\hline \multirow{2}{*}{ Adam Lake } & 36.58 & 122.76 & 0.75 & 6.83 & 14.80 & 1149.00 & 348.14 & 9.25 & 106.67 \\
\hline & \pm 5.02 & \pm 0.001 & \pm 0.04 & \pm 3.34 & \pm 6.12 & \pm 121.00 & \pm 117.54 & \pm 1.85 & \pm 41.63 \\
\hline \multirow{2}{*}{ Skimikin } & 26.08 & 110.63 & 0.79 & 1.60 & 3.00 & 329.10 & 140.41 & 3.48 & 236.67 \\
\hline & \pm 5.17 & \pm 23.70 & \pm 0.06 & \pm 0.01 & \pm 0.01 & \pm 87.08 & \pm 63.41 & \pm 1.05 & \pm 41.63 \\
\hline \multirow{2}{*}{ Tabor Lake } & 29.00 & 116.93 & 0.69 & 3.80 & 13.93 & 784.87 & 215.71 & 7.83 & 123.33 \\
\hline & \pm 8.34 & \pm 0.01 & \pm 0.08 & \pm 3.99 & \pm 4.50 & \pm 93.32 & \pm 44.28 & \pm 1.00 & \pm 15.28 \\
\hline \multirow{2}{*}{ Skeena River } & 23.04 & 131.89 & 0.65 & 11.67 & 23.13 & 939.78 & 264.10 & 7.98 & 147.50 \\
\hline & \pm 7.22 & \pm 9.75 & \pm 0.05 & \pm 2.44 & \pm 7.35 & \pm 422.00 & \pm 145.14 & \pm 1.29 & \pm 41.93 \\
\hline Chi-Square & 73.57 & 73.64 & 74.52 & 77.94 & 83.71 & 51.02 & 39.59 & 43.46 & 41.96 \\
\hline P Value & $<0.001$ & $<0.001$ & $<0.001$ & $<0.001$ & $<0.001$ & $<0.001$ & $<0.001$ & $<0.001$ & $<0.001$ \\
\hline
\end{tabular}


Table 4. Spearman's correlation between leaf characteristics (Chrs.) and climatic of paper birch populations' origin. The values are correlation coefficient and $\mathrm{N}=16$.

\begin{tabular}{|c|c|c|c|c|c|c|c|c|c|}
\hline Chrs. & LAT & LONG & ELE & MAP & MAT & MAI & GSP & GST & GSA \\
\hline LS & $-0.05^{\mathrm{ns}}$ & $0.29^{* *}$ & $0.26^{* *}$ & $-0.37^{* *}$ & $0.11^{\mathrm{ns}}$ & $-0.32^{* * *}$ & $-0.33^{* *}$ & $0.33^{* *}$ & $-0.36^{* *}$ \\
\hline SLA & $0.43^{* *}$ & $0.33^{* *}$ & $-0.11^{\text {ns }}$ & $0.06^{\mathrm{ns}}$ & $0.18^{*}$ & $-0.16^{*}$ & $-0.31^{* *}$ & $-0.29^{* *}$ & $-0.26^{* *}$ \\
\hline $\mathrm{AR}$ & $0.24^{* *}$ & $0.33^{* *}$ & $0.51^{* *}$ & $-0.53^{* *}$ & $0.08^{\mathrm{ns}}$ & $-0.53^{* *}$ & $-0.42^{* *}$ & $0.26^{* *}$ & $-0.44^{* *}$ \\
\hline $\mathrm{ADH}$ & $0.10^{\mathrm{ns}}$ & $-0.03^{\text {ns }}$ & $0.11^{\mathrm{ns}}$ & $-0.05^{\mathrm{ns}}$ & $-0.26^{* *}$ & $-0.15^{\text {ns }}$ & $0.02^{\mathrm{ns}}$ & $-0.21^{*}$ & $0.04^{\mathrm{ns}}$ \\
\hline $\mathrm{ABH}$ & $0.04^{\mathrm{ns}}$ & $0.18^{*}$ & $0.13^{\text {ns }}$ & $-0.23^{* *}$ & $-0.16^{*}$ & $-0.30^{* *}$ & $-0.17^{*}$ & $0.04^{\mathrm{ns}}$ & $-0.18^{*}$ \\
\hline SA & $-0.07^{\mathrm{ns}}$ & $0.35^{* *}$ & $0.05^{\mathrm{ns}}$ & $-0.12^{\mathrm{ns}}$ & $0.29^{*}$ & $-0.31^{*}$ & $-0.33^{* *}$ & $0.22^{*}$ & $-0.37^{* *}$ \\
\hline $\mathrm{PA}$ & $-0.08^{\mathrm{ns}}$ & $0.36^{* *}$ & $0.03^{\mathrm{ns}}$ & $-0.21^{\mathrm{ns}}$ & $0.19^{\mathrm{ns}}$ & $-0.32^{* *}$ & $-0.36^{* *}$ & $0.30^{*}$ & $-0.38^{* *}$ \\
\hline GCW & $-0.03^{\mathrm{ns}}$ & $0.35^{* *}$ & $0.03^{\text {ns }}$ & $-0.12^{\mathrm{ns}}$ & $0.30^{*}$ & $-0.32^{* *}$ & $-0.32^{* *}$ & $0.14^{\mathrm{ns}}$ & $-0.37^{* *}$ \\
\hline SD & $-0.14^{\mathrm{ns}}$ & $-0.36^{* *}$ & $-0.13^{\mathrm{ns}}$ & $0.24^{*}$ & $-0.05^{\mathrm{ns}}$ & $0.39^{\mathrm{ns}}$ & $0.39^{* *}$ & $-0.18^{\mathrm{ns}}$ & $0.38^{* *}$ \\
\hline SHC & $0.18^{\mathrm{ns}}$ & $-0.01^{\text {ns }}$ & $-0.04^{\mathrm{ns}}$ & $0.0^{\mathrm{ns}}$ & $0.02^{\mathrm{ns}}$ & $0.04^{\mathrm{ns}}$ & $-0.05^{\mathrm{ns}}$ & $-0.23^{*}$ & $-0.02^{\mathrm{ns}}$ \\
\hline SI & $-0.22^{*}$ & $-0.27^{*}$ & $-0.09^{\mathrm{ns}}$ & $0.01^{\mathrm{ns}}$ & $-0.07^{\mathrm{ns}}$ & $0.11^{\mathrm{ns}}$ & $0.26^{*}$ & $0.16^{\mathrm{ns}}$ & $0.22^{*}$ \\
\hline
\end{tabular}

Here *, ** is significant at $\mathrm{P}<0.05, \mathrm{P}<0.001$ respectively; ns: not significant.

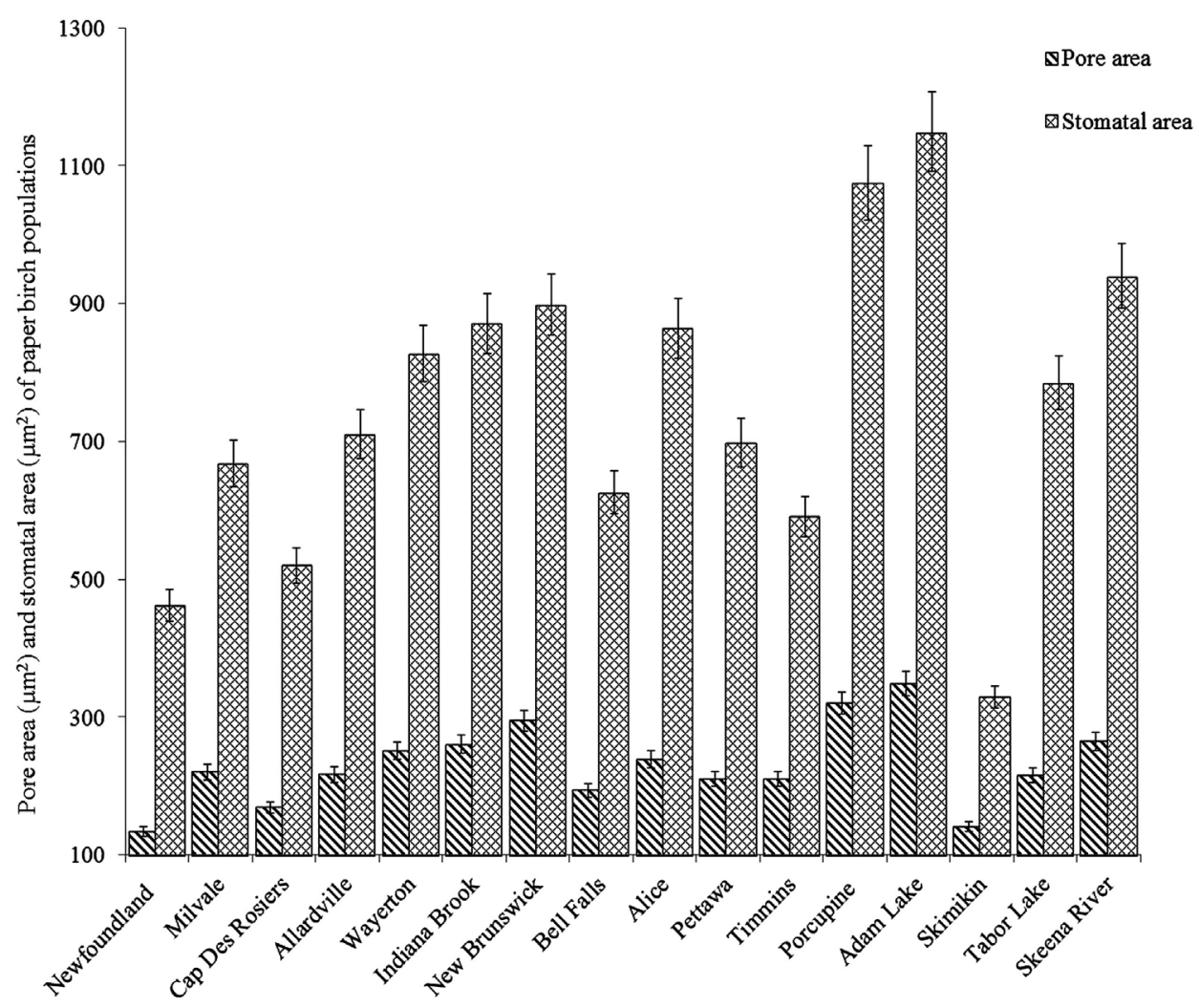

Paper birch population's origin across Canada (arranged from East to West longitude) Error bars: $95 \% \mathrm{CI}$

Figure 1. Intraspecific variations in stomatal area and pore area among paper birch. 
Table 5. Spearman's correlation coefficient (with p value in parenthesis) within of leaf morphological and stomatal characteristics (Chrs.) of $16(\mathrm{~N})$ paper birch populations collected (seeds) from across Canada and grown at the common garden in Thunder Bay-Ontario.

\begin{tabular}{|c|c|c|c|c|c|c|c|c|c|}
\hline & SA & PA & GCW & SD & SHC & LS & SLA & AR & $\mathrm{ABH}$ \\
\hline $\mathrm{PA}$ & $0.87^{* *}$ & & & & & & & & \\
\hline GCW & $0.84^{* *}$ & $0.55^{* *}$ & & & & & & & \\
\hline SD & $-0.72^{* *}$ & $-0.68^{* *}$ & $-0.56^{* *}$ & & & & & & \\
\hline SHC & $-0.20^{\mathrm{ns}}$ & $-0.24^{*}$ & $.07^{\mathrm{ns}}$ & $0.20^{\mathrm{ns}}$ & & & & & \\
\hline LS & $0.41^{\mathrm{ns}}$ & $0.34^{\mathrm{ns}}$ & $0.46^{\mathrm{ns}}$ & $-0.56^{*}$ & $-0.07^{\mathrm{ns}}$ & & & & \\
\hline SLA & $0.42^{\mathrm{ns}}$ & $0.35^{\mathrm{ns}}$ & $0.48^{\mathrm{ns}}$ & $-0.51^{*}$ & $0.39^{\mathrm{ns}}$ & $-0.14^{\mathrm{ns}}$ & & & \\
\hline $\mathrm{AR}$ & $0.18^{\mathrm{ns}}$ & $0.11^{\mathrm{ns}}$ & $0.27^{\mathrm{ns}}$ & $-0.38^{\text {ns }}$ & $0.03^{\mathrm{ns}}$ & $0.51^{* *}$ & $-0.04^{\mathrm{ns}}$ & & \\
\hline $\mathrm{ABH}$ & $0.41^{\mathrm{ns}}$ & $0.35^{\mathrm{ns}}$ & $0.43^{\text {ns }}$ & $-0.65^{*}$ & $-0.12^{\mathrm{ns}}$ & $-0.03^{\text {ns }}$ & $0.14^{\mathrm{ns}}$ & $0.17^{*}$ & \\
\hline $\mathrm{ADH}$ & $0.62^{*}$ & $0.55^{*}$ & $0.63^{*}$ & $-0.85^{* *}$ & $-0.17^{\mathrm{ns}}$ & $0.21^{*}$ & $0.14^{\mathrm{ns}}$ & $0.26^{*}$ & $0.80^{* *}$ \\
\hline
\end{tabular}

Here *, ** is significant at $\mathrm{p}<0.05, \mathrm{p}<0.001$ respectively; ns: not significant.

We found low hair density on leaf abaxial surface along increasing mean annual and growing season temperature gradients ( $\mathrm{r}=-0.26, \mathrm{P} \leq 0.001$ and $\mathrm{r}=-0.21, \mathrm{P} \leq 0.01$ respectively). Similarly, we found less hair density on adaxial surface with increasing mean annual precipitation $(r=-0.23, \mathrm{P} \leq 0.001)$ and aridity index $(\mathrm{r}=-0.30$, $\mathrm{P} \leq 0.001$ ) (Table 4).

Longitude, and growing season precipitation and aridity index of paper birch population's origin range from 57.57 - 128.34, 29.55 - $100.08 \mathrm{~mm}$ and 3.08 - 13.5, respectively (Table 1). All stomatal characteristic measured, except for stomatal shape coefficient, were significantly correlated with longitude, growing season precipitation and aridity $(\mathrm{P} \leq 0.05)$ (Table 4). Both stomatal area and guard cell width increased with longitude $(\mathrm{r}=0.35$ and 0.35 , respectively, $\mathrm{P} \leq 0.001)$ and a decrease in growing season precipitation $(\mathrm{r}=-0.33$ and $-0.32, \mathrm{P} \leq 0.001$ respectively) and aridity index $(\mathrm{r}=-0.37$ and -0.37 respectively, $\mathrm{P} \leq 0.001)$ (Table 4$)$. On the contrary, stomatal density decreased with an increase in longitude from east to west $(\mathrm{r}=-0.36, \mathrm{P} \leq 0.001)$, and the density was related to a decrease in mean annual and growing season precipitation $(r=0.24, p=0.03$ and $r=0.38$ respectively, $\mathrm{P} \leq 0.001)$ and aridity index ( $\mathrm{r}=0.39$ and 0.38 respectively, $\mathrm{P} \leq 0.001)$ (Table 4).

Along temperature gradient, we found that stomatal area and guard cell width were positively correlated to mean annual temperature ( $\mathrm{r}=0.29$ and 0.30 respectively, $\mathrm{P}=0.01)$ (Table 4). Similarly, stomatal area increased with increasing growing season temperature $(\mathrm{r}=0.22, \mathrm{P}=0.05)$ whereas, the stomatal shape coefficient decreased with an increase in the temperature $(\mathrm{r}=-0.23, \mathrm{P}=0.04)$. We found larger pore (area) in warmer temperature $(r=0.30, P \leq 0.01)$ associated with decreased precipitation $(r=-0.36, P \leq 0.001)$ and aridity index $(r=$ $-0.38, \mathrm{P} \leq 0.001$ ) during the growing season (Table 4). However, we found no significant correlation between stomatal index and the climate of the populations' origin. Furthermore, none of the stomatal characteristics were significantly related to latitude and elevation of the origin.

\subsection{Correlation between Leaf Morphological and Stomatal Characteristics}

Within a leaf morphological characteristic, we found significantly higher hair density on adaxial surface in larger leaf area $(r=0.21, P=0.01)$ and aspect ratio $(r=0.26, P=0.001)$ (Table 5). Within stomatal characteristics, increase in stomatal density significantly decreased stomatal area $(r=-0.72, P=0.001)$ (Figure 2), pore area ( $r$ $=-0.68, \mathrm{P}=0.001)$ and guard cell width $(\mathrm{r}=-0.56, \mathrm{P} \leq 0.001)$ (Table 5) Comparing leaf morphological and stomatal characteristics, we found that in stomatal density was more in smaller leaf area $(r=-0.56, P=0.03)$ and specific leaf area $(r=-0.51, P=0.05)$ with less hair densities on abaxial $(r=-0.65, P=0.01)$ and adaxial $(r$ $=-0.85, \mathrm{P} \leq 0.001)$ surfaces (Figure 3$)$. Adaxial hair density was more in leaves with larger stomatal area $(\mathrm{r}=$ $0.64, \mathrm{P}=0.01)$, pore area $(\mathrm{r}=0.55, \mathrm{P}=0.03)$ and guard cell width $(\mathrm{r}=0.63, \mathrm{P}=0.01)$. However these stomatal characteristics were insignificantly related to other leaf morphological characteristics (Table 5). 


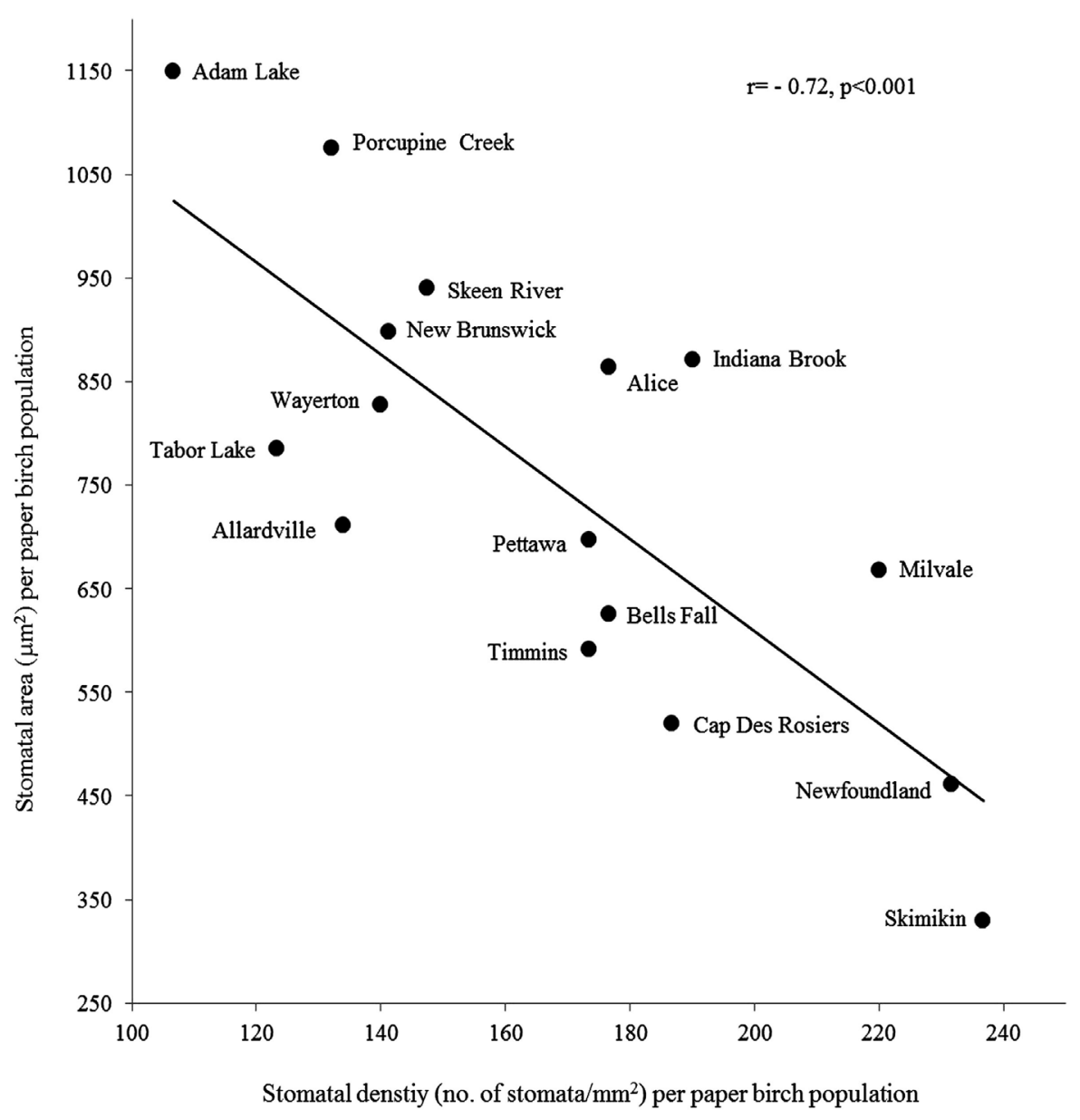

Figure 2. The correlation between stomatal density and size (area) for sixteen paper birch populations.

\section{Discussion}

The results of this study demonstrate significant variations in leaf morphological and stomatal characteristics of paper birch populations grown under uniform conditions in a common garden. The patterns in the variations are consistent with the results of other studies on Quercus petraea and Parkia biglobosa [1] [30]. The population variations observed in this study suggested that morphology and stomatal characteristics of the birch populations were maintained under a uniform environment, except for stomatal index and stomatal shape coefficient. This therefore supports the hypothesis that the birch populations significantly vary in leaf morphological and stomatal characteristics. These variations may be related to genotypic differences. It is possible therefore that environmental difference at population's origin identified among genotypes in this study and elsewhere [2] [39] had contributed to leaf variation in the paper birch populations.

We tested if genotypic differences in the leaf characteristics were related to the environment of the paper birch population's origin. Supporting our hypothesis, the results showed that the leaf characteristics that varied in the paper birch populations were significantly related to longitude and climate of the birch population's origin. Species show wide mechanism of adaptation to water deficiency such as reduction in leaf area, specific leaf area and aspect ratio [40] and/or increase in leaf hairiness [41]. Consistent with previous studies and supporting our third hypothesis, our results showed that paper birch leaves had higher adaxial hair density with decreasing annual precipitation and aridity index. Conversely, larger and wider leaf area was noticed in elevational, longitudinal and temperature (during growing season) gradients with decreasing precipitation and aridity index. Although our result did not support the hypothesis that smaller leaf originates in warmer region, the strong positive correlation between hair density on leaf adaxial surface and leaf area may explain reducing evapo-transpiration 


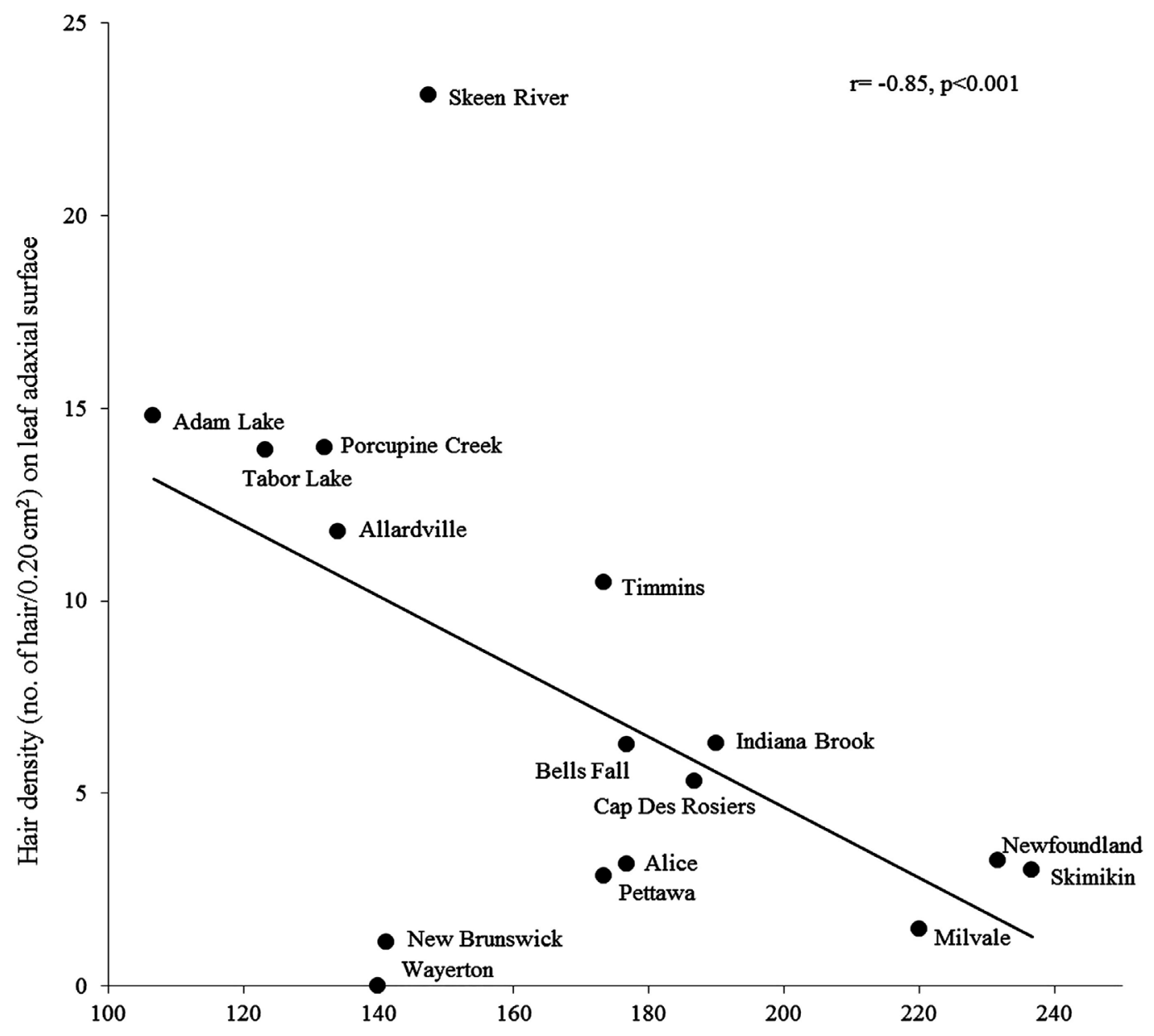

Stomatal denstiy (no. of stomata/mm²) per paper birch population

Figure 3. The correlation between mean stomatal density and leaf hair density on adaxial surface for sixteen paper birch populations.

from larger leaves in water deficiency. Similar to our result, most studies on intraspecific variation show an inconsistent relationship between leaf traits and climatic variables in comparison to interspecific variation. For instance, a study on Cistus salviifolius found bigger leaves in a drier area [42] whereas the opposite trend was found in Cistus ladanifer [43]. Similarly, an inconsistent relationship was found between leaf morphology of red ironbark and rainfall of different population origins [2]. The study on Cistus salviifolius demonstrated that leaf traits of plants grown in different conditions such as greenhouse generally differ from those in natural populations [42], which might be the case in our common garden study on paper birch.

In our study, longitude and aridity index (both mean annual and growing season) were major environmental variables that were significantly related to stomatal characteristics of paper birch. Stomatal area and density characterize species' resistance to drought [23] [44]. Small stomatal area with higher density was noticed in Populus trichocarpa from xeric environments [45] and stomatal density increased in Lolium perenne under elevated temperature [46]. In contrast to these studies, we found that paper birch had larger stomatal area and pore area with lower density in relation to decreasing precipitation and aridity index during the growing season. Even though our results did not support our hypothesis, it is consistent with a study on paper birch populations from water deficit sites that had larger and fewer stomata per unit area [47].

The tradeoff between stomatal area and density; that is, either larger stomatal area with low density or smaller stomatal area with high density, revealed by the strong correlations in our study, is consistent with other studies [18] [48]. Although stomatal area reduced with precipitation and aridity gradients in this study, stomatal area per 
unit leaf area remained unchanged due to an increase in stomatal density. Similar to our result, temperate species from drier habitats also had smaller stomatal area and higher stomatal densities that were associated with higher stomatal conductance [7]. Alternatively, larger stomatal area and lower stomatal density in deciduous tree species was associated with a slow increase in stomatal conductance under unfavorable conditions, such as warmer temperature [24]. Thus, we conclude that the tradeoff between stomatal area and density and their correlation to the climate of origin of the paper birch populations might be a strategy by the species to balance stomatal conductance in drier habitats. Furthermore, stomatal density and index revealed a negative relationship with increasing longitude, whereas stomatal area was positively related to longitude. Hence, populations that originated on the west coast had fewer stomatal densities with larger stomatal area in comparison to populations from the east coast. In the present study, we found no significant relationship between stomatal density and elevation, which was consistent with other studies [19] [49]. Results from previous studies on either increase or decrease of stomatal density to increased elevation were contradictory [50]. Moreover, in our study, stomatal area was positively correlated with the mean annual temperature of the origin which was consistent with previous studies [51]. Others suggest that small stomata can open and close more rapidly and would increase rapid stomatal conductance to maximize $\mathrm{CO}_{2}$ diffusion into the leaf, during favorable conditions [18].

Under environmental stress such as water deficiency, plants develop traits that either diminishes the loss of water or traits that reduce the need for water by increasing water use efficiency [52]. Small leaves with hairs could reduce transpiration by lowering leaf temperature or by changing boundary layer conditions [53] [54]. Furthermore, if small leaves had fewer stomata water use efficiency for a species will change. Although we did not subject the populations to any stress, increased precipitation and aridity index during the growing season at the origin positively increased stomatal density and decreased stomatal area, leaf area, specific leaf area and aspect ratio. Supporting our last hypothesis, our result showed significant correlations among stomatal density, size and leaf characteristics. Correlations between leaf morphological and stomatal characteristics revealed that populations with larger leaf area, specific leaf area and higher hair density had low stomatal density. Furthermore, populations with higher hair density on the adaxial surface had larger stomatal area, pore area and guard cell width. All these features provide a structural basis in reducing water loss through leaves and water use efficiency. However, we did not measure water use efficiency in this study. Nevertheless, leaf morphological and stomatal studies are valuable for identifying ecologically important traits that can then be further analyzed in other experiments [55] [56].

\section{Conclusion}

In conclusion, our results raise the possibility that intraspecific variation in paper birch might evolve due to genotypic variation and environmentally induced variation in leaf morphological and stomatal characteristics. Contrary to our expectations, several leaf characteristics were less related to environmental gradient of the birch's origin. Yet, we should consider the fact that the common garden was located at the climatic condition (mean annual precipitation $711 \mathrm{~mm}$, temperature $2.25^{\circ} \mathrm{C}$ and aridity index 74.73) that was different than the environment the populations would normally be exposed to. Thus, phenotypic plasticity of the birch possibly has imposed leaf characteristics contrary to our expectations to acclimate in the common garden environment [57]. Further studies involving the use of greenhouse experiment in plants grown under different environmental conditions are necessary to better understand how morphology and stomata vary in paper birch populations across Canada and their possible phenotypic plasticity to a changing climate.

\section{Acknowledgements}

The research was funded by NSERC discovery grant to JW. We appreciate Mrs. J. Lee, Profs M. Leitch and L. Hutchion for logistic support during greenhouse and laboratory experiments. We are grateful to Prof. A. Reif, Mr. S. F. Bartels and anonymous reviewers for their feedbacks.

\section{References}

[1] Teklehaimanot, Z., Lanek, J. and Tomlinson, H.F. (1998) Provenance Variation in Morphology and Leaflet Anatomy of Parkia biglobosa and Its Relation to Drought Tolerance. Trees, 13, 96-102. http://dx.doi.org/10.1007/PL00009742

[2] Warren, C.R., Tausz, M. and Adams, M.A. (2005) Does Rainfall Explain Variation in Leaf Morphology and Physiology among Populations of Red Ironbark (Eucalyptus sideroxylon subsp. Tricarpa) Grown in a Common Garden? Tree 
Physiology, 25, 1369-1378. http://dx.doi.org/10.1093/treephys/25.11.1369

[3] Ivancich, H.S., Lencinas, M.V., Pastur, G.J.M., Esteban1, R.M.S., Hernández, L. and Lindstrom, I. (2012) Foliar Anatomical and Morphological Variation in Nothofagus pumilio Seedlings under Controlled Irradiance and Soil Moisture Levels. Tree Physiology, 32, 554-564. http://dx.doi.org/10.1093/treephys/tps024

[4] Bloom, A.J., Chapin, F.S. and Mooney, H.A. (1985) Resource Limitation in Plants-An Economic Analogy. Annual Review of Ecology and Systematics, 16, 363-392. http://dx.doi.org/10.1146/annurev.es.16.110185.002051

[5] Mclellan, T. (2000) Geographic Variation and Plasticity of Leaf Shape and Size in Begonia dregei and B. homonyma (Begoniaceae). Botanical Journal of the Linnean Society, 132, 79-95. http://dx.doi.org/10.1006/bojl.1999.0292

[6] Abrams, M.D. (1990) Adaptations and Responses to Drought in Quercus Species of North America. Tree Physiology, 7, 227-238. http://dx.doi.org/10.1093/treephys/7.1-2-3-4.227

[7] Abrams, M.D. (1994) Genotypic and Phenotypic Variation as Stress Adaptations in Temperate Tree Species: A Review of Several Case Studies. Tree Physiology, 14, 833-842. http://dx.doi.org/10.1093/treephys/14.7-8-9.833

[8] Werger, M.J.A. and Ellenbroek, G.A. (1978) Leaf Size and Leaf Consistence of a Riverine Forest Formation along a Climatic Gradient. Oecologia, 34, 297-308. http://dx.doi.org/10.1007/BF00344908

[9] Gates, D. M. (1980) Biophysical Ecology. Springer Verlag, New York. http://dx.doi.org/10.1007/978-1-4612-6024-0

[10] Picotte, J.J., Rosenthal, D.M., Rhode, J.M. and Cruzan, M.B. (2007) Plastic Responses to Temporal Variation in Moisture Availability: Consequences for Water Use Efficiency and Plant Performance. Oecologia, 153, 821-832. http://dx.doi.org/10.1007/s00442-007-0794-z

[11] Ehleringer, J., Mooney, H.A., Gulmon, S.L. and Rundel, P.W. (1981) Parallel Evolution of Leaf Pubescence in Encelia in Coastal Deserts of North and South America. Oecologia, 49, 38-41. http://dx.doi.org/10.1007/BF00376895

[12] Fonseca, C.R., Overton, J.M., Collins, B. and Westoby, M. (2000) Shifts in Trait-Combinations along Rainfall and Phosphorus Gradients. Journal of Ecology, 88, 964-977. http://dx.doi.org/10.1046/j.1365-2745.2000.00506.x

[13] Cunningham, S.A., Summerhayes, B. and Westoby, M. (1999) Evolutionary Divergences in Leaf Structure and Chemistry, Comparing Rainfall and Soil Nutrient Gradients. Ecological Monographs, 69, 569-588. http://dx.doi.org/10.2307/2657231

[14] Pittermann, J. (2010) The Evolution of Water Transport in Plants: An Integrated Approach. Geobiology, 8, 112-139. http://dx.doi.org/10.1111/j.1472-4669.2010.00232.x

[15] Raven, J.A. and Edwards, D. (2001) Roots: Evolutionary Origins and Biogeochemical Significance. Journal of Experimental Botany, 52, 381-401. http://dx.doi.org/10.1093/jexbot/52.suppl_1.381

[16] Batos, B., Vilotić, D., Orlović, S. and Miljković, D. (2010) Inter and Intra-Population Variation of Leaf Stomatal Traits of Quercus robur L. in Northern Serbia. Archives of Biological Sciences, 62, 1125-1136. http://dx.doi.org/10.2298/ABS1004125B

[17] Beerling, D.J., Chaloner, W.G., Huntley, B., Pearson, J.A. and Tooley, M.J. (1993) Stomatal Density Responds to the Glacial Cycle of Environmental Change. Proceedings of the Royal Society B: Biological Sciences, 251, 133-138. http://dx.doi.org/10.1098/rspb.1993.0019

[18] Hetherington, A.M. and Woodward, F.I. (2003) The Role of Stomata in Sensing and Driving Environmental Change. Nature, 424, 901-908. http://dx.doi.org/10.1038/nature01843

[19] Holland, N. and Richardson, A.D. (2009) Stomatal Length Correlates with Elevation of Growth in Four Temperate Species. Journal of Sustain Forestry, 28, 63-73. http://dx.doi.org/10.1080/10549810802626142

[20] Raven, J.A. (2002) Selection Pressures on Stomatal Evolution. New Phytologist, 153, 371-386. http://dx.doi.org/10.1046/j.0028-646X.2001.00334.x

[21] Hawkins, B., Sharrock, S. and Havens, K. (2008) Plants and Climate Change: Which Future? Botanic Gardens Conservation International, Richmond.

[22] Fraser, L.H., Greenall, A., Carlyle, C., Turkington, R. and Friedman, C.R. (2009) Adaptive Phenotypic Plasticity of Pseudoroegneria spicata: Response of Stomatal Density, Leaf Area and Biomass to Changes in Water Supply and Increased Temperature. Annals of Botany, 103, 769-775. http://dx.doi.org/10.1093/aob/mcn252

[23] Belhadj, S., Derridj, A., Moriana, A., Gijon, M.D.C., Mevy, J.P. and Gauquelin, T. (2011) Comparative Analysis of Stomatal Characters in Eight Wild Atlas Pistachio Populations (Pistacia atlantica Desf.; Anacardiaceae). International Research Journal Plant Science, 2, 60-69.

[24] Aasamaa, K. and Sõber, A. (2011) Stomatal Sensitivities to Changes in Leaf Water Potential, Air Humidity, $\mathrm{CO}_{2} \mathrm{Con}_{-}$ centration and Light Intensity, and the Effect of Abscisic Acid on the Sensitivities in Six Temperate Deciduous Tree Species. Environmental and Experimental Botany, 71, 72-78. http://dx.doi.org/10.1016/j.envexpbot.2010.10.013

[25] Ashton, P.M.S. and Berlyn, G.P. (1994) A Comparison of Leaf Physiology and Anatomy of Quercus (Section Erythrobalanus-Fagaceae) Species in Different Light Environments. American Journal of Botany, 81, 589-597. 
http://dx.doi.org/10.2307/2445734

[26] Bacelare, E.A., Correia, C.M., Pereira, J.M.M., Gonçalves, B.C., Lopes, J.I. and Torres-Pereira, J.M.G. (2004) Sclerophylly and Leaf Anatomical Traits of Five field-Grown Olive Cultivars Growing under Drought Conditions. Tree Physiology, 24, 233-239. http://dx.doi.org/10.1093/treephys/24.2.233

[27] Bayramzadeh, V. (2011) Stomatal Characteristics of Fagus orientalis Lipsky in Geographically Separated Locations in the Caspian Forests of Northern Iran. Research Journal of Environmental Sciences, 5, 836-840. http://dx.doi.org/10.3923/rjes.2011.836.840

[28] Safford, L., Bjorkbom, J.C. and Zasada, J.C. (1990) Betula papyrifera Marsh. Paper Birch. In: Burns, R.M. and Honkala, B.H., Eds., Silvics of the Forest Trees of the United States, Agriculture Handbook-2, Washington DC.

[29] Hovenden, M.J. and Schoor, J.K.V. (2003) Nature vs. Nurture in the Leaf Morphology of Southern Beech, Nothofaguscunninghamii (Nothofagaceae). New Phytologist, 161, 585-594.

[30] Bruschi, P., Grossoni, P. and Bussoti, F. (2003) Within and among Tree Variation in Leaf Morphology of Quercus petrea (Matt.) Liebl. Natural Populations. Trees, 17, 164-172.

[31] Bruschi, P., Vendramin, G.G., Bussotti, F.A. and Grossoni, P. (2000) Morphological and Molecular Differentiation between Quercus petraea (Matt.) Liebl. and Quercus pubescens Willd. (Fagaceae) in Northern and Central Italy. Annals of Botany, 85, 325-333. http://dx.doi.org/10.1006/anbo.1999.1046

[32] Xu, Z. and Zhou, G. (2008) Responses of Leaf Stomatal Density to Water Status and Its Relationship with Photosynthesis in a Grass. Journal of Experimental Botany, 59, 3317-3325. http://dx.doi.org/10.1093/jxb/ern185

[33] Pompelli, M.F., Martin, S.C.V., Celin, E.F., Ventrella, M.C. and Damatta, F.M. (2010) What is the Influence of Ordinary Epidermal Cells and Stomata on the Leaf Plasticity of Coffee Plants Grown under Full-Sun and Shady Conditions? Brazilian Journal of Biology, 70, 1083-1088. http://dx.doi.org/10.1590/S1519-69842010000500025

[34] Sagaram, M. and Lombardini, L. (2007) Variation in Leaf Anatomy of Pecan Cultivars from Three Ecogeographic Locations. Journal of the American Society for Horticultural Science, 132, 592-596.

[35] Royer, D.L. (2001) Stomatal Density and Stomatal Index as Indicators of Paleoatmospheric $\mathrm{CO}_{2}$ Concentration. Review of Palaeobotany and Palynology, 114, 1-28. http://dx.doi.org/10.1016/S0034-6667(00)00074-9

[36] De Martonne, E. (1926) Aréisme et Indice d’aridité. Comptes Rendus de L’Academy of Science, Paris, 1395-1398.

[37] Migalina, S., Ivanova, L. and Makhnev, A. (2009) Size of the Leaf as a Marker of Birch Productivity at a Distance from the Climatic Optimum. Russian Journal of Plant Physiology, 56, 858-862. http://dx.doi.org/10.1134/S102144370906017X

[38] Sjors, H. (1974) Ekologiskklimatlara-Stencil. Växtbiologiska Institutionen, Uppsala 23 Sidor.

[39] Hughes, A.R., Stachowicz, J.J. and Willams, S.L. (2009) Morphological and Physiological Variation among Seagrass (Zostera marina) Genotypes. Oecologia, 159, 725-733. http://dx.doi.org/10.1007/s00442-008-1251-3

[40] Kundu, S.K. and Tigerstedt, P.M.A. (1997) Geographical Variation in Seed and Seedling Traits of Neem (Azadirachta indica) among Ten Populations Studied in Growth Chamber. Silvae Genetica, 46, 2-3.

[41] Johnson, H.B. (1975) Plant Pubescence: An Ecological Perspective. The Botanical Review, 41, 233-258. http://dx.doi.org/10.1007/BF02860838

[42] Farley, R.A. and Mcneilly, T. (2000) Diversity and Divergence in Cistus salvifolius (L.) Populations from Contrasting Habitats. Hereditas, 132, 183-192. http://dx.doi.org/10.1111/j.1601-5223.2000.t01-1-00183.X

[43] Nunez-Olivera, E., Martinez-Abaigar, J. and Escudero, J.C. (1996) Adaptability of Leaves of Cistusladanifer to Widely Varying Environmental Conditions. Functional Ecology, 10, 636-646. http://dx.doi.org/10.2307/2390174

[44] Balok, C.A. and Hilaire, R.S. (2002) Drought Responses among Seven Southwestern Landscape Tree Taxa. Journal of the American Society for Horticultural Science, 127, 211-218

[45] Dunlap, J.M. and Stettler, R.F. (2001) Variation in Leaf Epidermal and Stomatal Traits of Populus trichocarpa from Two Transects across the Washington Cascades. Canadian Journal of Botany, 79, 528-536.

[46] Ferris, R., Nijs, I., Behaeghe, T. and Impens, I. (1996) Elevated $\mathrm{CO}_{2}$ and Temperature Have Different Effects on Leaf Anatomy of Perennial Ryegrass in Spring and Summer. Annals of Botany, 78, 489-497. http://dx.doi.org/10.1006/anbo.1996.0146

[47] Li, W.L., Berlyn, G.P. and Ashton, P.M.S. (1996) Polyploids and Their Structural and Physiological Characteristics Relative to Water Deficit in Betula papyrifera (Betulaceae). American Journal of Botany, 83, 15-20. http://dx.doi.org/10.2307/2445949

[48] Camargo, M.A.B. and Maremco, R.A. (2011) Density, Size and Distribution of Stomata in 35 Rainforest Tree Species in Central Amazonia. Acta Amazonica, 41, 205-212. http://dx.doi.org/10.1590/S0044-59672011000200004

[49] Russo, S.E., Cannon, W.L., Elowsky, C., Tan, S. and Davies, S.J. (2010) Variation in Leaf Stomatal Traits of 28 Tree 
Species in Relation to Gas Exchange along an Edaphic Gradient in a Bornean Rain Forest. American Journal of Botany, 97, 1109-1120. http://dx.doi.org/10.3732/ajb.0900344

[50] Körner, C. (1999) Alpine Plant Life: Functional Plant Ecology of High Mountain Ecosystem. Springer, Heidelberg. http://dx.doi.org/10.1007/978-3-642-98018-3

[51] Hilaire, R.S. and Graves, W.R. (1999) Foliar Traits of Sugar Maples and Black Maples near $43^{\circ}$ N Latitude in the Eastern and Central United State. Journal of the American Society for Horticultural Science, 124, 605-611.

[52] Dudley, S.A. (1996) Differing Selection on Plant Physiological Traits in Response to Environmental Water Availability: A Test of Adaptive Hypotheses. Evolution, 50, 92-102. http://dx.doi.org/10.2307/2410783

[53] Givnish, T.J. (1979) On the Adaptive Significance of Leaf Form. In: Solbrig, O.T., Jain, S., Johnson, G.B. and Raven, P.H., Eds., Topics in Plant Population Biology, Columbia University Press, New York.

[54] Roy, B.A., Stanton, M.L. and Eppley, S.M. (1999) Effects of Environmental Stress on Leaf Hair Density and Consequences for Selection. Journal of Evolutionary Biology, 12, 1089-1103.

[55] Lande, R. and Arnold, S.J. (1983) The Measurement of Selection on Correlated Characters. Evolution, 37, $1210-1226$. http://dx.doi.org/10.2307/2408842

[56] Wade, M.J. and Kalisz, S.J. (1990) The Causes of Natural Selection. Evolution, 44, 1947-1955. http://dx.doi.org/10.2307/2409605

[57] Pearce, D.W., Millard, S., Bray, D.F. and Rood, S.B. (2006) Stomatal Characteristics of Riparian Poplar Species in a Semi-Arid Environment. Tree Physiology, 26, 211-218. http://dx.doi.org/10.1093/treephys/26.2.211 